\title{
KAJIAN DAN EVALUASI PEMUSTAKA UNIT PELAKSANA JASA PDII-LIPI DI SERPONG
}

\author{
Rahartri \\ Pusat Dokumentasi dan Informasi Ilmiah - LIPI \\ Korespondensi: rahartris@yahoo.com
}

Diajukan: 20-06-2018; Direview: 28-08-2018; Diterima: 03-09-2018; Direvisi: 02-11-2018

\begin{abstract}
The study aims to evaluate the number of UPJ PDII-LIPI Serpong visitors from 2010 - 2016. The study was carried out descriptively, with data sources obtained from visitor books and UPJ PDII-LIPI Serpong monthly reports. More in-depth information was explored from the visitors regarding factors that influenced the interest of visitors. Based on the results of the analysis, it can be concluded that: (1) total visitors to UPJ PDII-LIPI Serpong from 2010 - 2016 are as many as 2331 people (41,8\%) from the Puspiptek area (LIPI, BPPT, BATAN, PPIT, KLHK; and 58,2\% from outside the Puspiptek region (school students, university students, the general public, industry, and institutions outside the Puspiptek area); (2) visitors from the Puspiptek area are dominated by LIPI followed by BPPT, BATAN, PPIT, and KLHK. While visitors from outside the Puspiptek area are dominated by school students, then followed by university students, the general public, industry, and institutions outside Puspiptek area; (3) the purposes of visitors to UPJ PDII-LIPI Serpong are to get references, do observations, literature studies, comparative studies, reading, browsing internet, working on research assignments/reports, and consulting about libraries; (4) the decreasing a number of visitors at UPJ PDII-LIPI Serpong.
\end{abstract}

\begin{abstract}
ABSTRAK
Kajian ini bertujuan untuk mengevaluasi jumlah pengunjung UPJ PDII-LIPI Serpong selama tahun 2010 2016. Kajian dilakukan secara deskriptif, dengan sumber data buku pengunjung dan laporan bulanan UPJ PDII-LIPI Serpong. Informasi lebih mendalam digali dari para pengunjung terkait faktor yang mempengaruhi minat kedatangan pengunjung. Berdasarkan hasil analisis dapat disimpulkan bahwa: (1) total pengunjung UPJ PDII-LIPI Serpong 2010 - 2016 sejumlah 2331 orang, yang terdiri dari 41,8\% berasal dari dalam kawasan Puspiptek (LIPI, BPPT, BATAN, PPIT, KLHK; dan 58,2\% berasal dari luar kawasan Puspiptek (pelajar, mahasiswa, masyarakat umum, industri, dan instansi di luar kawasan Puspiptek); (2) pengunjung dari dalam kawasan Puspiptek didominasi oleh LIPI, kemudian diikuti BPPT, BATAN, PPIT, dan KLHK. Sementara pengunjung dari luar kawasan Puspiptek didominasi oleh kalangan pelajar, kemudian diikuti mahasiswa, masyarakat umum, industri, dan instansi di luar kawasan Puspiptek; (3) tujuan pengunjung ke UPJ PDII-LIPI Serpong adalah mencari referensi, observasi, studi literatur, studi banding, membaca, browsing internet, mengerjakan tugas/laporan penelitian, dan konsultasi tentang perpustakaan; (4) penurunan jumlah pengunjung di UPJ PDII-LIPI Serpong.
\end{abstract}

Keywords: Library services; User need; Research services; Collections; Special library; PDII-LIPI

\section{PENDAHULUAN}

Pusat Penelitian Ilmu Pengetahuan dan Teknologi (Puspiptek) merupakan kawasan terpadu yang didirikan berdasarkan Keppres No.43/1976 tanggal 1 Oktober 1976. Puspiptek memiliki luas daerah 460Ha dengan 50 Pusat/Balai litbang dimana SDM lebih dari 5000 orang. Peran Puspiptek adalah sebagai pusat penguasaan dan pengembangan iptek; pusat pendidikan dan latihan untuk SDM industri; pusat pelayanan pengembangan produk nasional; pusat alih teknologi dan pusat informasi iptek; dan pusat pengembangan kewirausahaan dan inkubasi baru/UKMK berbasis teknologi. Kawasan Puspiptek digunakan untuk menempatkan sejumlah pusat penelitian milik LIPI, BPPT, BATAN, dan Kementerian Lingkungan Hidup dan Kehutanan (KLHK). LIPI memiliki lima pusat penelitian di kawasan Puspiptek, yaitu: 
Pusat Penelitian Metalurgi dan Material (P2MM); Pusat Penelitian Kimia (P2K); Pusat Penelitian Fisika (P2F); Pusat Penelitian Metrologi (P2M); Pusat Penelitian Sistem Mutu dan Teknologi Pengujian (P2SMTP).

Laboratorium LIPI yang berada di Kawasan Puspiptek merupakan laboratorium pengujian standar dan laboratorium yang meneliti ilmu-ilmu dasar. Badan Pengkajian dan Penerapan Teknologi (BPPT) memiliki 34 Pusat/Balai Litbang di Kawasan Puspiptek, koordinasinya di bawah Kedeputian Pengkajian Kebijakan Teknologi; Kedeputian Teknologi Pengembangan Sumberdaya Alam; Kedeputian Teknologi Agroindustri dan Bioteknologi; Kedeputian Teknologi Informasi Industri Rancang Bangun dan Rekayasa. Badan Tenaga Nuklir Nasional (BATAN) memiliki 10 Pusat yang berada di kawasan Puspiptek. BATAN memiliki reaktor nuklir serbaguna yang bernama G.A.Siwabessy, yang berfungsi sebagai sarana penelitian baik di bidang kenukliran maupun di bidang kesehatan. BATAN juga melaksanakan penelitian di bidang kesehatan, bahan bakar nuklir, dan limbah nuklir. Kementerian Lingkungan Hidup dan Kehutanan (KLHK) memiliki dua pusat penelitian di kawasan Puspiptek Serpong, yaitu: Pusat Penelitian dan Pengembangan Kualitas dan Laboratorium Lingkungan (P3KL), yang berfungsi sebagai pemantauan lingkungan; dan Puslatmas dan Pengembangan Generasi Lingkungan, yang berfungsi sebagai lembaga pendidikan dan pelatihan.

Di kawasan Puspiptek juga terdapat Unit Pelaksana Jasa (UPJ) PDII-LIPI Serpong, yang melaksanakan tugas pemberian jasa informasi ilmu pengetahuan dan teknologi (iptek) sejak tahun 1993. UPJ PDII-LIPI Serpong bertujuan untuk memberikan kemudahan layanan informasi iptek bagi peneliti yang sedang melaksanakan kegiatan penelitian di kawasan Puspiptek Serpong. Seiring berjalannya waktu, pengunjung UPJ PDII-LIPI Serpong semakin menurun dari tahun ke tahun. Subagyo (2009) mengatakan faktor-faktor yang mempengaruhi tinggi rendahnya persentase maupun frekuensi kunjungan ke perpustakaan, diantaranya: (1) kesibukan, pengguna perpustakaan banyak pekerjaan sehingga tidak sempat ke perpustakaan; (2) kebutuhan informasi, perpustakaan masih kurang dalam menyediakan informasi terutama informasi yang mutakhir; (3) isu adanya informasi yang berkembang dari mulut ke mulut bahwa perpustakaan tersebut koleksinya tidak lengkap (padahal belum tentu benar); (4) perpustakaan sebagai sumber pengayaan pengetahuan; (5) perpustakaan dapat memenuhi informasi untuk kebutuhan diskusi; dan (6) akses internet.

Penelitian ini menjelaskan tentang profil pengunjung UPJ PDII-LIPI Serpong tahun 2010 - 2016, baik pengunjung yang berasal dari dalam kawasan Puspiptek maupun luar kawasan Puspiptek Serpong. Selain itu, kajian ini untuk mengetahui tujuan mereka berkunjung dan faktor-faktor yang menyebabkan menurunnya jumlah kunjungan peneliti ke UPJ PDII-LIPI Serpong.

\section{TINJAUAN PUSTAKA}

\subsection{Layanan Perpustakaan}

Undang-Undang (UU) No.43 Tahun 2007 tentang Perpustakaan menyebutkan bahwa perpustakaan adalah institusi pengelola koleksi karya tulis, karya cetak, dan/atau karya rekam secara profesional dengan sistem yang baku guna memenuhi kebutuhan pendidikan, penelitian, pelestarian, informasi, dan rekreasi para pemustaka. Perpustakaan berfungsi sebagai wahana pendidikan, penelitian, pelestarian, informasi, dan rekreasi untuk meningkatkan kecerdasan dan keberdayaan bangsa. Perpustakaan bertujuan memberikan layanan kepada pemustaka, meningkatkan kegemaran membaca, serta memperluas wawasan 
dan pengetahuan untuk mencerdaskan kehidupan bangsa. UU tersebut juga menyebutkan bahwa: (a) layanan perpustakaan dilakukan secara prima dan berorientasi bagi kepentingan pemustaka; (b) setiap perpustakaan menerapkan tata cara layanan perpustakaan berdasarkan standar nasional perpustakaan; (c) layanan perpustakaan dikembangkan melalui pemanfaatan sumber daya perpustakaan untuk memenuhi kebutuhan pemustaka; (d) layanan perpustakaan diselenggarakan sesuai dengan standar nasional perpustakaan untuk mengoptimalkan pelayanan kepada pemustaka; (e) layanan perpustakaan terpadu diwujudkan melalui kerja sama antar perpustakaan.

Witjaksono (2009) mengatakan tujuan layanan perpustakaan adalah untuk dimanfaatkan semaksimal mungkin oleh pemustaka. Sangat penting bagi perpustakaan untuk lebih mengoptimalkan kinerja dalam memenuhi kebutuhan pemakainya. Perpustakaan harus mengupayakan cara agar pemustaka merasa memiliki perpustakaan, membutuhkan perpustakaan, dan merasakan manfaat yang besar dari perpustakaan. Layanan perpustakaan yang berbasis pada teknologi informasi dan komunikasi menjanjikan kecepatan layanan dan hal tersebut menjadi salah satu faktor penting dalam pelayanan perpustakaan (Rulyah, 2006). Aplikasi teknologi informasi di perpustakaan secara optimal akan mampu mengatasi kendalakendala dalam pelayanan perpustakaan, seperti kecepatan, ketepatan, dan keakuratan informasi yang dilayankan (Suhartika, 2004). Shen (2006) mengatakan ada beberapa konsep alternatif layanan perpustakaan, diantaranya: (1) menyenangkan dan nyaman (desain interior modern, ruang musik, pameran seni, peralatan teknologi yang menyesuaikan); (2) adanya petugas yang ramah (memberikan nasehat kepada pengunjung, layanan multimedia, dapat melayani dengan jarak jauh, menyediakan layanan teknis); (3) dapat digunakan untuk diskusi dan belajar kelompok, diskusi tentang publikasi, bimbingan pemakai database, ruang pertemuan reguler bagi peneliti, lokakarya dan simposium.

Yadnya (2006) mengatakan sukses tidaknya pelayanan suatu perpustakaan tergantung pada tiga faktor, yaitu: (1) fasilitas dan kelengkapan gedung ruang perpustakaan; (2) tersedianya koleksi bahan pustaka yang ada; (3) profesionalisme staf perpustakaan yang bersangkutan. Kemudian, untuk meningkatkan kualitas layanan perpustakaan, Yadnya (2007) menjelaskan ada beberapa cara, yaitu: (1) sebagai pelayan dapat memahami secara mendalam bahwa dirinya adalah pelayan jasa di perpustakaan; (2) memiliki prinsip atau slogan $\angle O M B O K$, yaitu seorang pelayan harus: Luwes dalam pergaulan, ber-Orientasi kemasa depan, Mатри dalam melaksanakan pekerjaan dan mengarahkan pemakai jasa, Berkelanjutan dalam meningkatkan layanan, Optimalisasi dalam pemberian layanan, Kreativitas tinggi untuk kemajuan perpustakaan; 3) memiliki sifat-sifat yang positif; 4) memiliki dasar pengetahuan tentang pelayanan; 5) melaksanakan lima unsur pelayanan.

\subsection{Tujuan ke Perpustakaan}

Fransisca (2013) mengatakan setiap pengguna yang berkunjung ke perpustakaan memiliki tujuan yang berbeda-beda. Ada yang hanya sekedar mencari hiburan, ada yang menikmati layanan yang disediakan oleh perpustakaan, bahkan ada yang mencari informasi untuk pemenuhan kebutuhan informasinya. Pengguna yang datang ke perpustakaan juga memiliki motivasi, baik motivasi internal maupun motivasi eksternal. Motivasi internal merupakan dorongan dari dalam diri seseorang untuk memenuhi kebutuhannya. Motivasi internal yang dimiliki oleh pengguna perpustakaan, seperti untuk memenuhi kebutuhan informasinya - menyelesaikan tugas, menyelesaikan pekerjaan, atau menambah informasi. Sementara itu, motivasi eksternal merupakan dorongan dari luar yang mampu menunjang diri 
seseorang untuk memenuhi kebutuhannya. Motivasi eksternal pengguna, seperti adanya fasilitas yang disediakan oleh perpustakaan untuk menunjang pencarian informasi oleh pengguna. Adanya fasilitas penunjang maka pengguna lebih mudah untuk mendapatkan informasi, seperti adanya Online Public Access Catalogue (OPAC) untuk sarana temu kembali informasi. Sebagian pengunjung datang ke perpustakaan untuk mencari informasi, melepaskan lelah setelah kuliah, mengerjakan tugas untuk dikumpulkan, melakukan diskusi kelompok, dan bertemu dengan teman (Gunarti dalam Fransisca, 2013). Laporan Audit Commission (2002) menyebutkan bahwa banyak orang mengunjungi perpustakaan untuk belajar, menggunakan komputer dan internet, bertanya, atau membuat kegiatan masyarakat.

\subsection{Minat Kunjung ke Perpustakaan}

Peningkatan jumlah perpustakaan yang membangun halaman web menyebabkan pengguna memiliki akses ke berbagai layanan tanpa perlu fisik memasuki perpustakaan (Rao $\&$ Babu, 2001). Melalui sumber informasi global (internet) telah menggeser peran perpustakaan sebagai media utama untuk mendapatkan informasi, dan saat ini masyarakat lebih sering menggunakan internet sebagai media untuk mendapatkan informasi (Mardion, dkk, 2013). Lebih lanjut Mardion, dkk (2013) mengatakan menurunnya jumlah pengunjung perpustakaan dapat disebabkan karena bahan pustaka yang kurang lengkap, kualitas pelayanan yang kurang baik, atau karena terjadi perubahan perilaku konsumen. Menurunnya jumlah pengunjung perpustakaan juga berdampak pada kurang termanfaatkannya koleksi bahan pustaka yang ada di perpustakaan.

Berdasarkan hasil penelitian, Hasanah (2013) mengatakan ada beberapa faktor yang mempengaruhi minat kunjung pemustaka di perpustakaan fakultas kedokteran Universitas Gadjah Mada, yang dipengaruhi oleh faktor yaitu kebutuhan, koleksi yang lengkap, pelayanan yang ramah, suasana yang nyaman, dan fasilitas perpustakaan untuk tempat ujian. Meisyaroh (2014) menjelaskan ada beberapa faktor yang mempengaruhi minat kunjung pemustaka di Kantor Arsip dan Perpustakaan Kabupaten Klaten, yaitu: (1) kurangnya kesadaran masyarakat tentang fungsi dari perpustakaan sebagai pusat informasi; (2) koleksi perpustakaan, yaitu dengan kelengkapan koleksi, kesesuaian koleksi dan kemutahiran koleksi yang tidak bisa memberikan kepuasan kepada pemustaka; (3) fasilitas perpustakaan, yaitu letak gedung yang kurang strategis dan letak yang sulit diketahui pemustaka, penataan koleksi yang tidak sistematis dapat menyulitkan pemustaka dalam mencari koleksi yang diinginkan, fasilitas yang kurang memenuhi kebutuhan pemustaka salah satunya adalah tidak adanya fasilitas OPAC dan fasilitas internet, serta ruangan yang tidak sesuai dengan kebutuhan pemustaka; (4) kinerja pustakawan, yaitu pustakawan yang kurang baik dalam melayani pemustaka, sikap pustakawan yang pasif kepada pemustaka.

Lance at al (2011) mengatakan bahwa faktor yang mempengaruhi tinggi rendahnya pengunjung, yaitu: (1) tersedianya tempat yang nyaman untuk membaca, belajar dan diskusi; (2) perpustakaan menyediakan tempat untuk mencari buku, menggunakan internet dan menyelenggarakan program yang dapat menarik pengunjung. Laporan Audit Commission (2002) menyebutkan bahwa ada beberapa faktor yang menyebabkan pengunjung menurun adalah koleksi, jam buka perpustakaan. Untuk meningkatkan jumlah pengunjung perlu memahami apa yang mereka butuhkan, aksesibilitas layanan dan kenyamanan. 


\section{METODE}

Kajian dilakukan secara deskriptif. Subjek kajian ini adalah pengunjung UPJ PDII-LIPI Serpong tahun 2010 - 2016. Data diperoleh dari buku pengunjung dan dari laporan bulanan UPJ PDII-LIPI Serpong tahun 2010-2016. Data primer (kuantitatif) yang terkumpul kemudian diolah dengan Microsoft Excel dalam bentuk tabulasi frekuensi, yakni dengan mengelompokkan pengunjung berdasarkan keberagaman profil. Data dianalisis dan dijabarkan dalam bentuk gambar/grafik. Keberagaman profil meliputi: pengunjung dari dalam kawasan Puspiptek dan pengunjung dari luar kawasan Puspiptek. Pengunjung dari dalam kawasan Puspiptek mencakup: peneliti LIPI dan peneliti non-LIPI (BBPT, BATAN, PPIT, dan KLHK-diwakili oleh PUSARPEDAL). Sedangkan pengunjung dari luar kawasan Puspiptek, mencakup pelajar, mahasiswa, masyarakat umum, industri, dan instansi diluar kawasan Puspiptek. Informasi lebih mendalam digali dari para pengunjung terkait faktor yang mempengaruhi minat kedatangan pengunjung dan disajikan secara deskriptif untuk mendukung dan memperkuat analisis kuantitatif. Hasil dan pembahasan menjadi dasar penyusunan kesimpulan kajian ini.

\section{HASIL DAN PEMBAHASAN}

\subsection{Pengunjung UPJ PDII-LIPI Serpong}

Tujuan layanan UPJ PDII-LIPI Serpong adalah untuk memberikan kemudahan layanan informasi bagi peneliti untuk menunjang kegiatan penelitian, khususnya di kawasan Puspiptek Serpong. Pada tahun 2010 - 2016, minat pengunjung ke UPJ PDII-LIPI Serpong, baik dari kelompok peneliti LIPI maupun peneliti non-LIPI, cenderung mengalami penurunan setiap tahunnya, seperti terlihat pada Gambar 1.

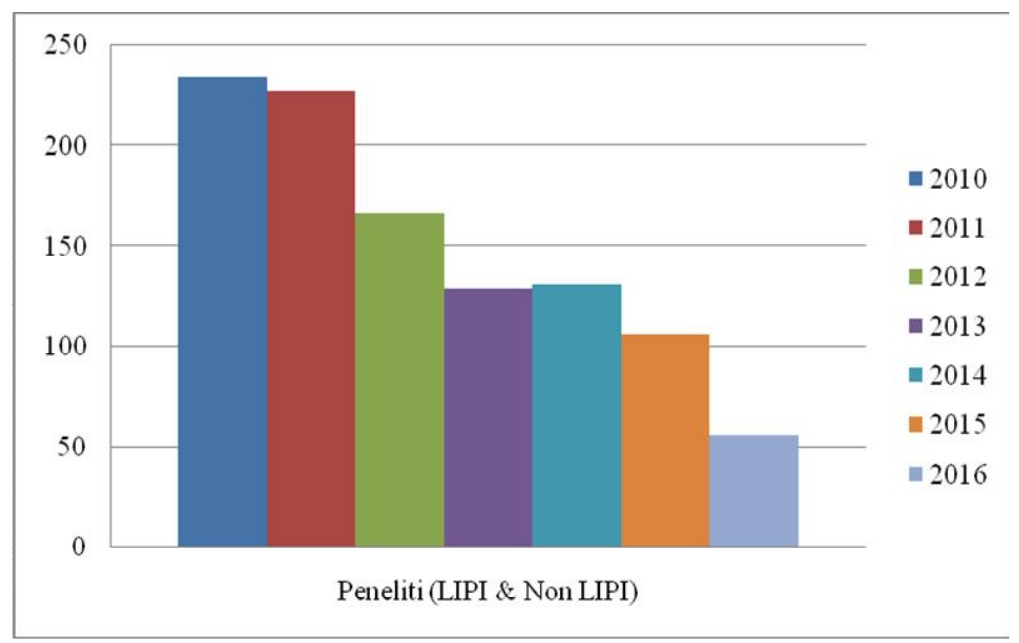

Gambar 1. Grafik kunjungan peneliti ke UPJ PDII-LIPI Serpong

Berdasarkan hasil wawancara dengan peneliti, diketahui bahwa menurunnya jumlah kunjungan peneliti ke UPJ PDII-LIPI Serpong karena informasi yang dibutuhkan oleh peneliti sebagian besar sudah tercukupi dari informasi jurnal di ScienceDirect yang dilanggan oleh Kemenristek-Dikti. Selain itu, informasi yang diperlukan peneliti sering tersedia gratis di internet dan banyaknya peneliti yang sedang tugas belajar (baik dalam negeri maupun luar negeri) yang memberikan database informasi fulltext ke peneliti juga menjadi penyebab menurunnya jumlah kunjungan ke UPJ PDII-LIPI Serpong. 


\subsection{Pengunjung Dari Dalam Kawasan Puspiptek}

Tabel 1 menunjukkan jumlah pengunjung tertinggi ke UPJ PDII-LIPI Serpong berasal dari LIPI (50,87\%). Kemudian diikuti oleh BPPT (24,46\%), BATAN (14,18\%), PPIT $(10,38 \%)$ dan KLHK $(0,10 \%)$. Pengunjung dari LIPI paling banyak karena buku-buku yang diperlukan oleh peneliti LIPI didokumentasikan di UPJ PDII-LIPI Serpong. Sedangkan pengunjung dari KLHK jumlahnya paling sedikit karena KLHK memiliki perpustakaan sendiri dengan koleksi yang sesuai dengan kebutuhan penelitinya.

Tabel 1. Pengunjung dari Dalam Kawasan Puspiptek

\begin{tabular}{|c|c|c|}
\hline Instansi & $\begin{array}{l}\text { Jumlah } \\
\text { (orang) }\end{array}$ & $\begin{array}{c}\text { Persentase } \\
(\%)\end{array}$ \\
\hline LIPI & 495 & 50,87 \\
\hline BPPT & 238 & 24,46 \\
\hline BATAN & 138 & 14,18 \\
\hline PPIT & 101 & 10,38 \\
\hline KLHK & 1 & 0,10 \\
\hline Total & 973 & 100 \\
\hline
\end{tabular}

Gambar 2 menunjukkan bahwa secara umum terjadi penurunan jumlah kunjungan dari masing-masing instansi yang berada di dalam kawasan Puspiptek ke UPJ PDII-LIPI Serpong tahun 2010 - 2016.

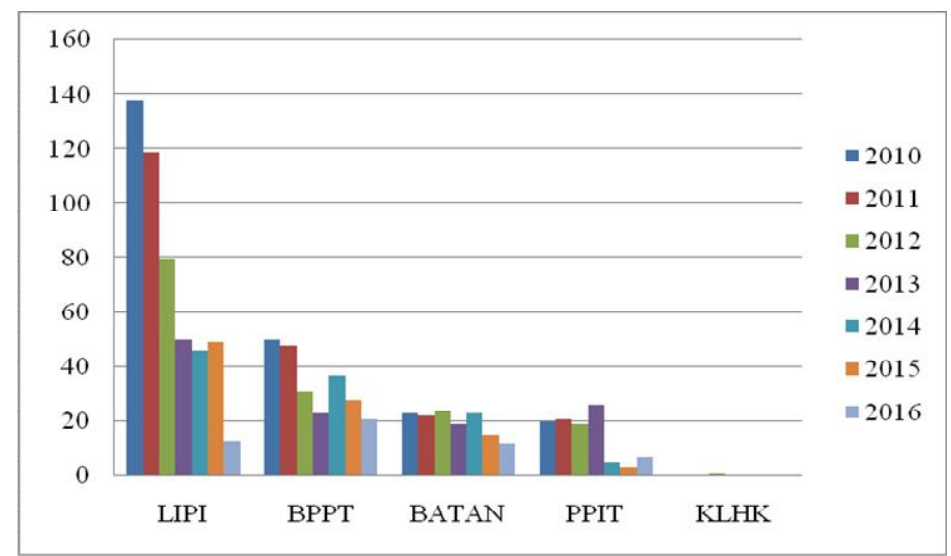

Gambar 2. Grafik kunjungan dari dalam kawasan Puspiptek

Berdasarkan hasil wawancara dengan pengunjung, diketahui bahwa Kemenristek-Dikti telah melanggankan jurnal asing online dari ScienceDirect yang dapat diakses fulltext oleh seluruh pegawai/peneliti di bawah koordinasi Kemenristek-Dikti, seperti LIPI, BPPT, BATAN, LAPAN, PPIT, dan KLHK. Pada tahun 2012 - 2013, Kemenristek-Dikti juga melanggan standar ASTM yang dapat diakses fulltext oleh seluruh pegawai/peneliti di bawah Kemenristek-Dikti. Misalnya, BPPT telah melanggan database Standar IEC dan ISO yang dapat diakses gratis oleh peneliti BPPT dan pemustaka dari instansi lain yang datang ke Perpustakaan BPPT, baik yang berlokasi di kawasan Puspiptek Serpong maupun Perpustakaan BPPT yang ada di Jakarta. Hal tersebut juga menyebabkan menurunnya minat kunjungan pemustaka ke UPJ PDII LIPI Serpong. 


\subsubsection{Pengunjung dari LIPI}

Tabel 2 menunjukkan bahwa kunjungan paling banyak berasal dari Pusat Penelitian Metalurgi \& Material (P2MM), dengan jumlah pengunjung 155 orang (31,31\%). Sedangkan tiga satuan kerja, yaitu Pusat Penelitian Metrologi (P2M), Pusat Penelitian Bioteknologi, dan Pusat Penelitian Sistem Mutu dan Teknologi Pengujian (P2SMTP) masing-masing melakukan kunjungan kurang dari 10\%. Tujuan mereka kunjungan ke UPJ PDII-LIPI Serpong, yaitu mencari dokumen standar atau dokumen lainnya, mengerjakan tugas penelitian, studi banding perpustakaan, konsultasi tentang perpustakaan, atau bermain internet dengan menggunakan laptop (memanfaatkan jaringan wifi yang tersedia).

Tabel 2. Pengunjung dari LIPI

\begin{tabular}{|c|c|c|}
\hline Unit kerja & $\begin{array}{l}\text { Jumlah } \\
\text { (orang) }\end{array}$ & $\begin{array}{c}\text { Persentase } \\
(\%)\end{array}$ \\
\hline P2 Metalurgi \& Material & 155 & 31,31 \\
\hline P2 Kimia & 98 & 19,80 \\
\hline PDII & 64 & 12,93 \\
\hline P2 Fisika & 62 & 12,53 \\
\hline P2 Metrologi & 43 & 8,69 \\
\hline P2 Bioteknologi & 37 & 7,47 \\
\hline P2 SMTP & 36 & 7,27 \\
\hline Total & 495 & 100 \\
\hline
\end{tabular}

Gambar 3 menunjukkan bahwa pada tahun 2010 - 2013, kunjungan didominasi oleh Pusat Penelitian Metalurgi dan Material (P2MM). Sedangkan pada tahun 2014 - 2015, kunjungan didominasi oleh Pusat Penelitian Kimia (P2K). Kunjungan peneliti dari kedua satuan kerja tersebut sering dilakukan dalam rangka melaksanakan tugas penelitian. Mereka berpendapat bahwa perpustakaan atau UPJ PDII-LIPI Serpong merupakan tempat yang nyaman untuk mengerjakan tugas penelitian.

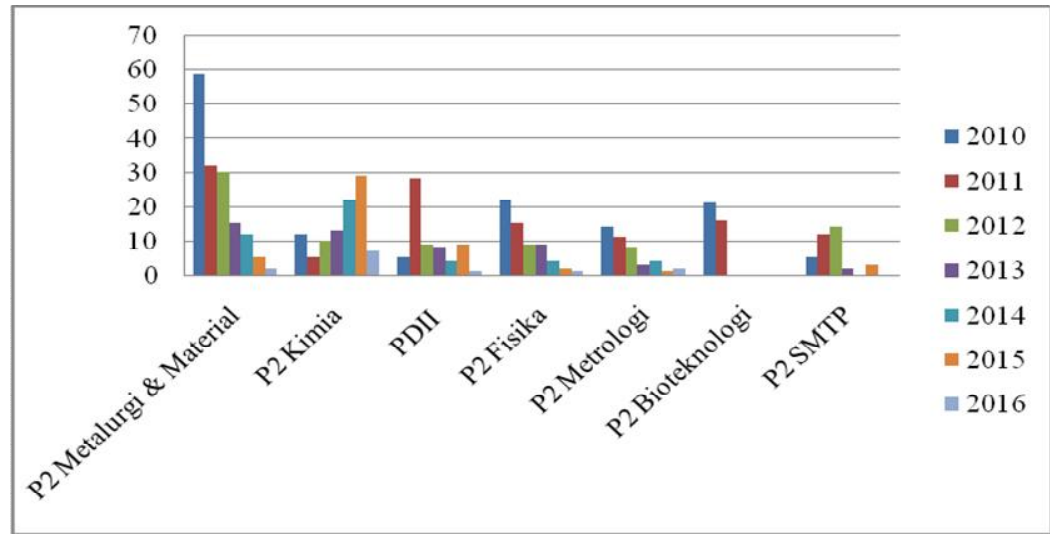

Gambar 3. Grafik pengunjung dari LIPI

Berdasarkan Gambar 3 terlihat bahwa pada tahun 2016 juga terjadi penurunan jumlah kunjungan dari peneliti Penelitian Metalurgi dan Material (P2MM) dan Pusat Penelitian Kimia $(\mathrm{P} 2 \mathrm{~K})$ karena mereka sedang tugas belajar ke luar negeri. 


\subsubsection{Pengunjung dari BPPT}

Tabel 3 menunjukkan jumlah pengunjung BPPT tahun 2010 - 2016. Dalam kurun waktu tersebut diketahui 238 orang pegawai BPPT yang berkunjung ke UPJ PDII-LIPI Serpong. Berdasarkan Tabel 3 dan Gambar 4 dapat diketahui bahwa kunjungan didominasi oleh Balai Besar Teknologi Kekuatan Struktur (B2TKS) dan Balai Pengkajian Teknologi Polimer (BPTP), masing-masing sejumlah 96 orang $(40,34 \%)$ dari B2TKS dan 74 orang $(31,09 \%)$ dari BPTP.

Tabel 3. Pengunjung dari BPPT

\begin{tabular}{|c|c|c|}
\hline Unit kerja & $\begin{array}{l}\text { Jumlah } \\
\text { (Orang) }\end{array}$ & $\begin{array}{c}\text { Persentase } \\
(\%)\end{array}$ \\
\hline B2TKS & 96 & 40,34 \\
\hline BPTP & 74 & 31,09 \\
\hline BPBiotek & 26 & 10,92 \\
\hline B2TE & 10 & 4,20 \\
\hline BTMP & 8 & 3,36 \\
\hline LABTIAB & 7 & 2,94 \\
\hline PTL & 6 & 2,52 \\
\hline MEPPO & 4 & 1,68 \\
\hline BIT & 2 & 0,84 \\
\hline GEOSTECH & 2 & 0,84 \\
\hline LAGG & 1 & 0,42 \\
\hline PTM & 1 & 0,42 \\
\hline PTPSE & 1 & 0,42 \\
\hline Total & 238 & 100 \\
\hline
\end{tabular}

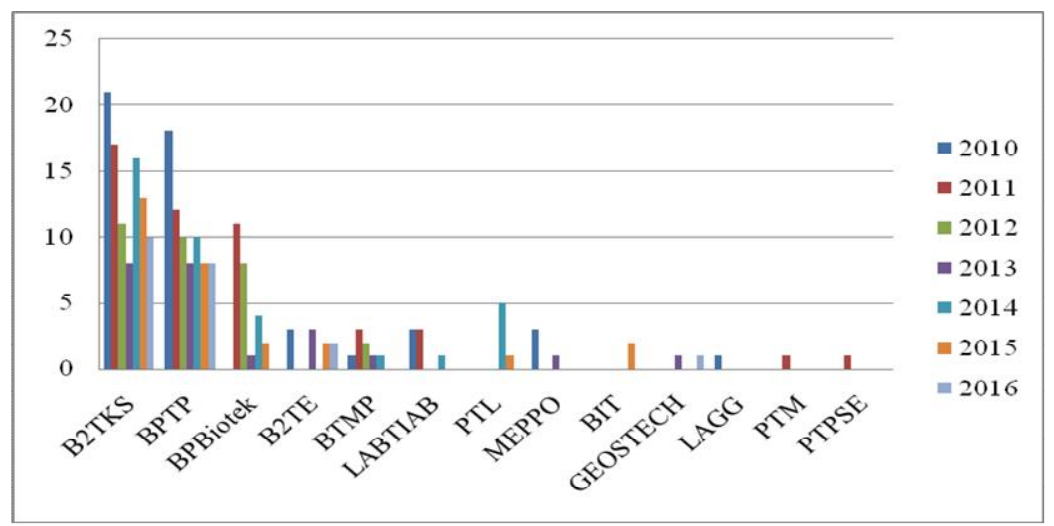

Gambar 4. Grafik pengunjung dari BPPT

\section{Keterangan:}

$\begin{array}{ll}\text { B2TKS } & =\text { Balai Besar Teknologi Kekuatan Struktur } \\ \text { BPTP } & =\text { Balai Pengkajian Teknologi Polimer } \\ \text { BPBiotek } & =\text { Balai Pengkajian Bioteknologi } \\ \text { B2TE } & =\text { Balai Besar Teknologi Energi } \\ \text { BTMP } & =\text { Balai Termodinamika, Motor, dan Propulsi } \\ \text { LABTIAB } & =\text { Pusat Teknologi Bioindustri } \\ \text { PTL } & =\text { Pusat Teknologi Lingkungan } \\ \text { MEPPO } & =\text { Mesin Perkakas, Produksi \& Otomasi } \\ \text { BIT } & =\text { Balai Inkubator Teknologi } \\ \text { GEOSTECH } & =\text { Laboratoria Teknologi Sistem Kebumian } \\ \text { LAGG } & =\text { Laboratorium Aero Gas Dinamika dan Getaran } \\ \text { PTM } & =\text { Pusat Teknologi Material } \\ \text { PTPSE } & =\text { Pusat Teknologi Pengembangan Sumberdaya Energi }\end{array}$


Berdasarkan Gambar 4 terlihat bahwa pada tahun 2010 - 2016 terjadi penurunan minat kunjungan ke UPJ PDII-LIPI Serpong karena pegawai BPPT telah memperoleh informasi dari jurnal yang dilanggan oleh Kemenristek-Dikti dan BPPT, akses dari internet, dan mendapat informasi dari teman kerja yang sedang tugas belajar. Selain itu, padatnya aktivitas di kantor unit kerja menyulitkan para pegawai BPPT untuk berkunjung ke perpustakaan UPJ PDII-LIPI Serpong.

Berbeda halnya dengan kunjungan yang dominan dilakukan oleh pegawai B2TKS dan BPTP. Pada umumnya jenis informasi yang diperlukan oleh kedua satuan kerja tersebut adalah koleksi standar, seperti standar American Welding Society (AWS), Association of American Railroads (AAR), British Standards (BS), International Union of Railways (UIC), Japanese Industrial Standard (JIS), dan koleksi standar lainnya. Dengan demikian, mereka membutuhkan bantuan penelusuran dokumen maupun pengadaan dokumen lengkapnya melalui petugas UPJ PDII-LIPI Serpong.

\subsubsection{Pengunjung dari BATAN}

Pada tahun 2010 - 2016 UPJ PDII-LIPI Serpong juga menerima kunjungan dari pegawai BATAN. Dalam kurun waktu tersebut diketahui 138 orang pegawai BATAN yang telah berkunjung ke UPJ PDII-LIPI Serpong (Tabel 4).

Tabel 4. Pengunjung dari BATAN

\begin{tabular}{|c|c|c|}
\hline Unit kerja & $\begin{array}{l}\text { Jumlah } \\
\text { (Orang) }\end{array}$ & $\begin{array}{c}\text { Persentase } \\
(\%)\end{array}$ \\
\hline PTBBN & 70 & 50,72 \\
\hline PTRKN & 13 & 9,42 \\
\hline PSTBM & 11 & 7,97 \\
\hline PRPN & 11 & 7,97 \\
\hline PTBIN & 10 & 7,25 \\
\hline PRSG & 5 & 3,62 \\
\hline PTLR & 5 & 3,62 \\
\hline P2TBDU & 4 & 2,9 \\
\hline BATEK & 4 & 2,9 \\
\hline P3IB & 3 & 2,17 \\
\hline PUSBATAN & 2 & 1,45 \\
\hline Total & 138 & 100 \\
\hline
\end{tabular}

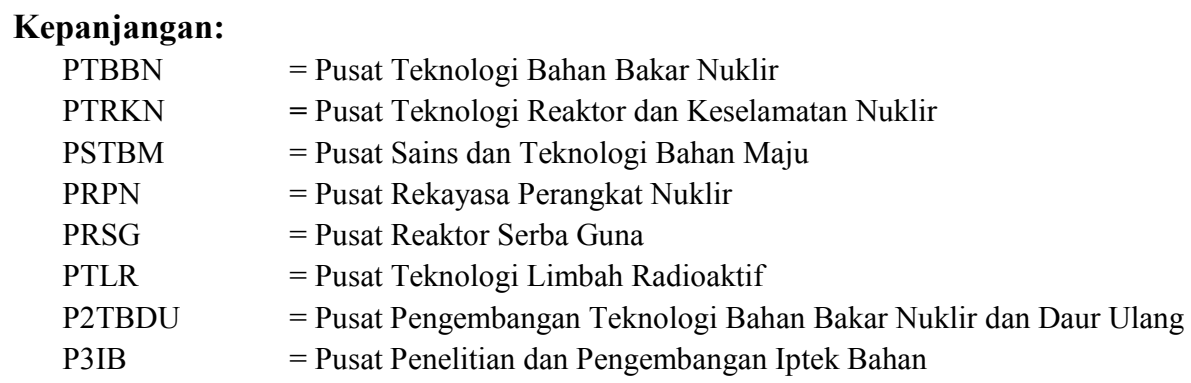

Berdasarkan Tabel 4 dan Gambar 5 juga diketahui bahwa kunjungan dari BATAN didominasi oleh Pusat Teknologi Bahan Bakar Nuklir (PTBBN), yakni 70 orang (50,72\%), sedangkan kunjungan pegawai BATAN dari PTRKN, PSTBM, PRPN, PTBIN, PRSG, PTLR, P2TBDU, BATEK, P3IB, dan PUSBATAN kurang dari 10\%. 


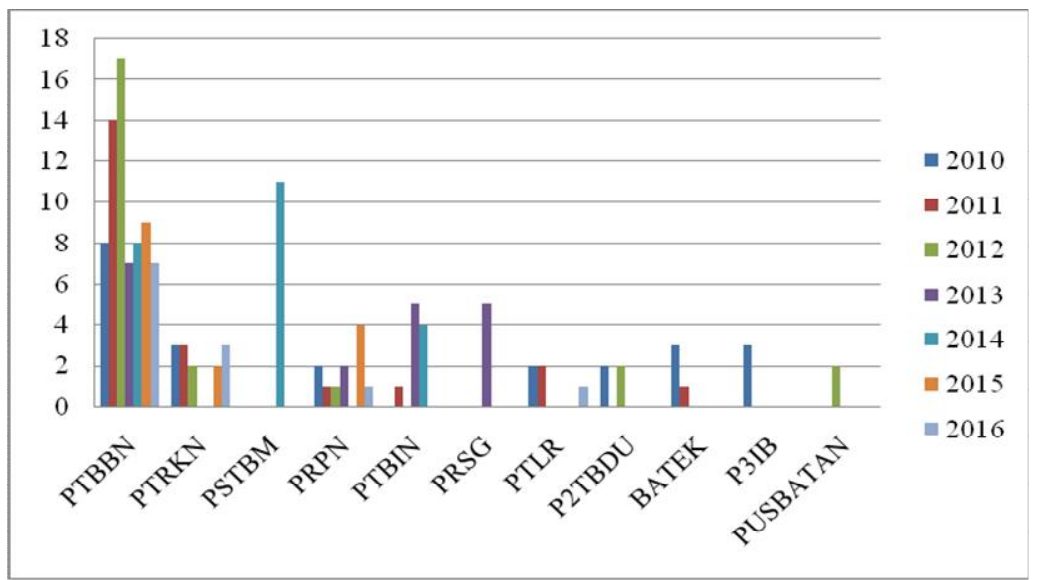

Gambar 5. Grafik pengunjung dari BATAN

Berdasarkan hasil wawancara dengan beberapa pegawai BATAN, penurunan minat kunjungan ke perpustakaan dipengaruhi oleh perubahan peraturan atau sistem kerja kepegawaian di instansinya sejak diberikan tunjangan kinerja. Aturan yang sangat ketat bagi para pegawai BATAN yang akan keluar kantor hanya dapat dilakukan ketika mendapatkan penugasan resmi dari atasannya.

\subsubsection{Pengunjung dari PPIT dan KLHK}

Pengunjung dari PPIT dan KLHK ke UPJ PDII-LIPI Serpong sangat sedikit, yakni 1 kali kunjungan pada tahun 2010 - 2016. Mereka datang ke UPJ PDII-LIPI Serpong umumnya sekedar membaca koleksi perpustakaan.

\subsection{Pengunjung dari Luar Kawasan Puspiptek}

Pada tahun 2010 - 2016 diketahui 1.358 orang yang berkunjung ke UPJ PDII-LIPI Serpong. Jumlah pengunjung dari luar kawasan Puspiptek lebih banyak dibandingkan pengunjung dari dalam kawasan Puspiptek. Sebaran jumlah pengunjung dari luar kawasan Puspiptek berdasarkan pekerjaannya dapat dilihat dalam Tabel 5.

Tabel 5. Pengunjung dari Luar Kawasan Puspiptek

\begin{tabular}{|l|c|c|}
\hline \multicolumn{1}{|c|}{ Instansi } & $\begin{array}{c}\text { Jumlah } \\
\text { (orang) }\end{array}$ & $\begin{array}{c}\text { Persentase } \\
(\%)\end{array}$ \\
\hline Pelajar & 637 & 46,91 \\
\hline Mahasiswa & 374 & 27,54 \\
\hline Masyarakat/Umum & 144 & 10,60 \\
\hline Industri & 127 & 9,35 \\
\hline Instansi di luar Kawasan Puspiptek & 76 & 5,60 \\
\hline \multicolumn{1}{|c|}{ Total } & $\mathbf{1 . 3 5 8}$ & $\mathbf{1 0 0}$ \\
\hline
\end{tabular}

Gambar 6 juga menunjukkan ada kenaikan dan penurunan jumlah pengunjung ke UPJ PDII-LIPI Serpong. Jumlah kunjungan terbanyak dari kelompok pelajar, khususnya pada tahun 2015. Mereka termotivasi karena adanya tugas membuat karya tulis ilmiah pada sekolah-sekolah di sekitar kawasan Puspiptek. Banyaknya pelajar dari Sekolah Menengah Kejuruan (SMK) yang melakukan praktek kerja lapangan di kawasan Puspiptek juga menjadi meningkatnya jumlah kunjungan ke UPJ PDII-LIPI Serpong. 


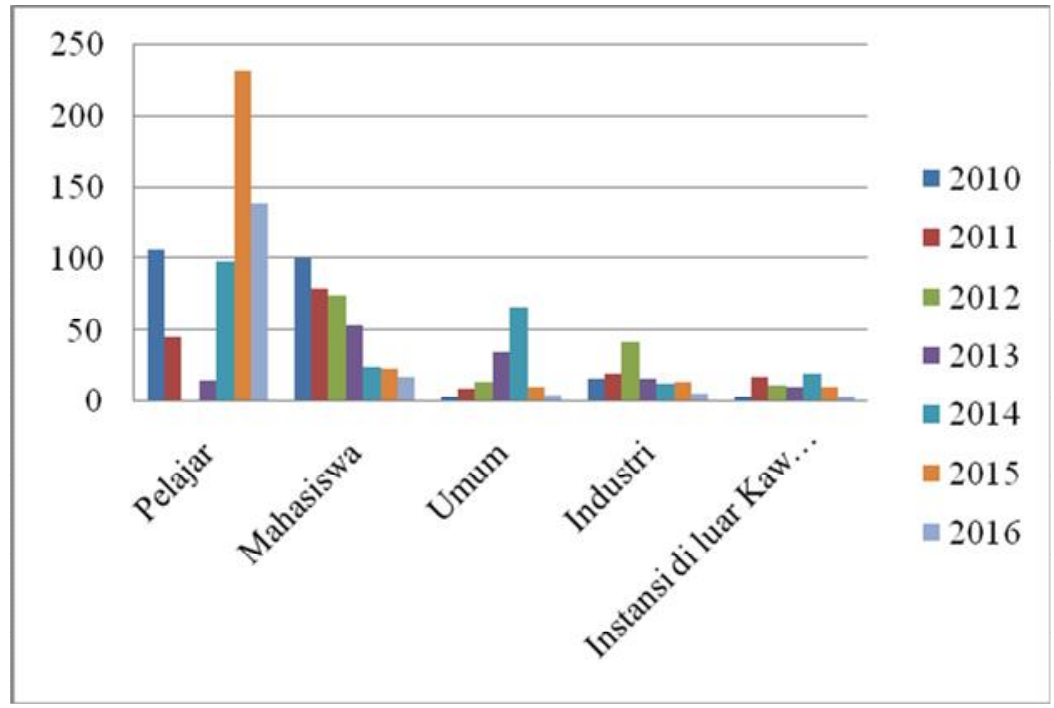

Gambar 6. Grafik pengunjung dari luar kawasan Puspiptek

Pada umumnya mahasiswa yang melakukan kunjungan ke UPJ PDII-LIPI Serpong adalah mereka yang sedang mencari data atau melakukan penelitian di satuan kerja yang ada di kawasan Puspiptek Serpong. Selain itu, adanya peningkatan kemampuan dan keahlian dalam bidang penelitian dan pengembangan inovasi oleh pelajar dan mahasiswa dari sekolah dan perguruan tinggi (swasta atau negeri) juga menjadi meningkatnya jumlah pengunjung UPJ PDII-LIPI Serpong. Adanya kemudahan akses informasi dan literatur bagi masyarakat di luar kawasan Puspitek; tidak adanya persyaratan keanggotaan perpustakaan; kesempatan untuk melakukan praktek kerja juga mendorong minat baca dan kunjungan para pelajar dan mahasiswa ke UPJ PDII-LIPI Serpong.

\subsubsection{Pengunjung Kelompok Pelajar}

Tabel 6 menunjukkan sebaran jumlah pengunjung kelompok pelajar dan Gambar 7 menunjukkan grafik kenaikan dan penurunan jumlah pengunjung kelompok pelajar pada tahun $2010-2016$.

Tabel 6. Pengunjung Kelompok Pelajar

\begin{tabular}{|l|c|c|}
\hline Pelajar & $\begin{array}{c}\text { Jumlah } \\
\text { (orang) }\end{array}$ & $\begin{array}{c}\text { Persentase } \\
(\mathbf{\% )})\end{array}$ \\
\hline SD & 4 & 0,63 \\
\hline SMP & 107 & 16,80 \\
\hline SMA & 39 & 6,12 \\
\hline SMK & 487 & 76,45 \\
\hline Total & $\mathbf{6 3 7}$ & $\mathbf{1 0 0}$ \\
\hline
\end{tabular}




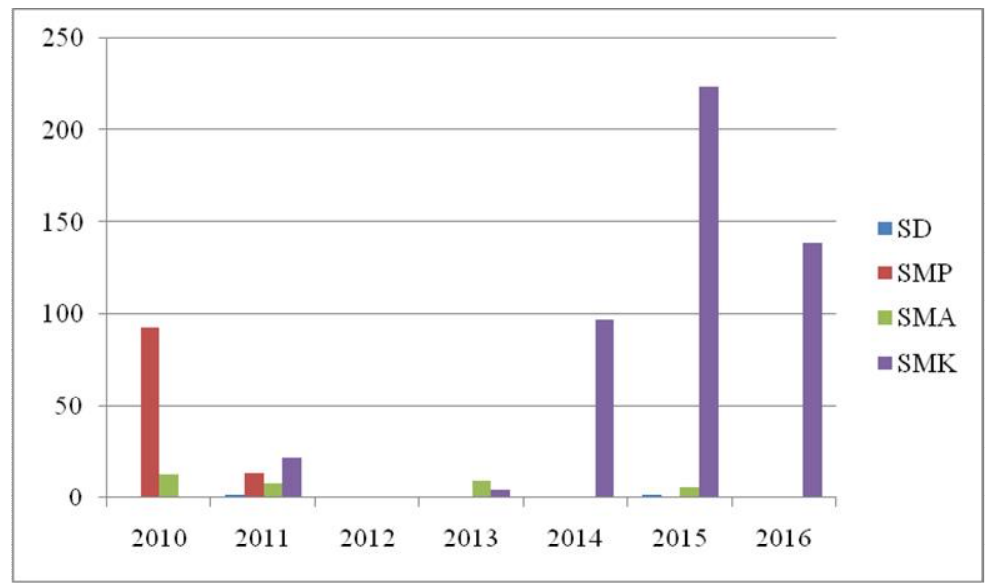

Gambar 7. Grafik pengunjung dari kelompok pelajar

Dari Gambar 7 terlihat juga bahwa kunjungan oleh kelompok pelajar SD, SMP, dan SMA cenderung menurun, sedangkan kunjungan oleh kelompok pelajar SMK cenderung meningkat. Hal tersebut disebabkan banyaknya pelajar SMK yang melakukan praktek kerja di kawasan Puspiptek. Sepuluh kelompok pelajar yang dominan melakukan kunjungan ke UPJ PDII-LIPI Serpong pada tahun 2010 - 2016 ditunjukkan pada Gambar 8.

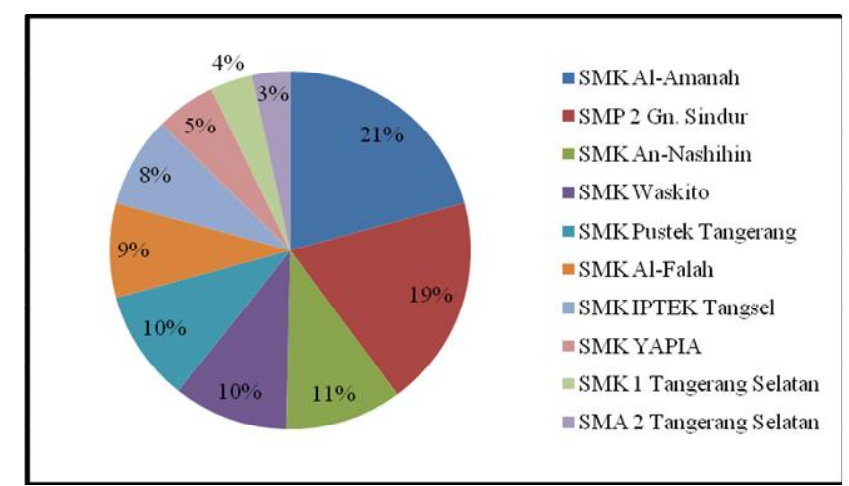

Gambar 8. Diagram pengunjung dari kelompok pelajar (10 besar)

\subsubsection{Pengunjung Kelompok Mahasiswa}

Tujuan mahasiswa berkunjung ke UPJ PDII-LIPI Serpong adalah untuk mencari referensi, observasi, studi literatur, studi banding, mengerjakan laporan penelitian, mencari informasi standar, mencari dokumen paten, dan mengakses internet. Gambar 9 dan Gambar 10 menunjukkan jumlah pengunjung UPJ PDII-LIPI Serpong dari kelompok mahasiswa tahun 2010-2016. 


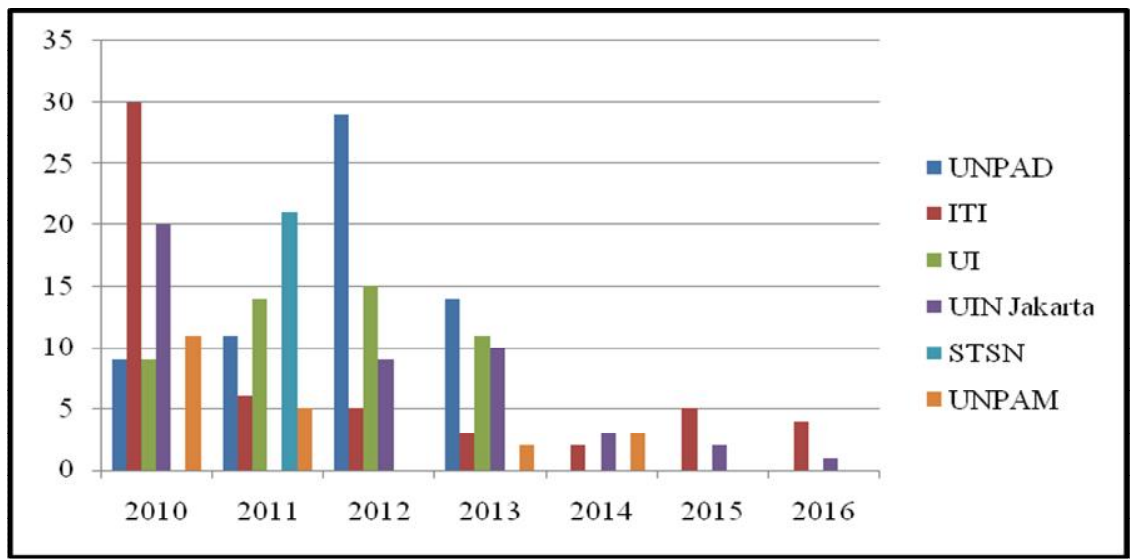

Gambar 9. Grafik pengunjung dari kelompok mahasiswa

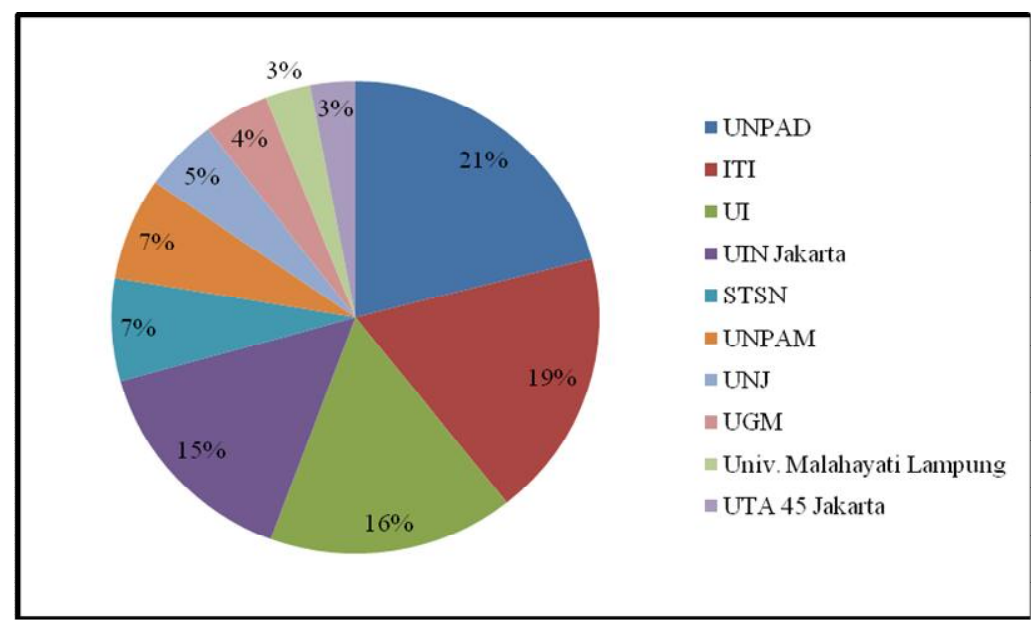

Gambar10. Diagram pengunjung dari kelompok mahasiswa (10 besar)

Berdasarkan Gambar 10 terlihat juga bahwa pada tahun 2010 - 2016, jumlah kunjungan terbanyak adalah dari Universitas Padjadjaran - Bandung. Kemudian, diikuti oleh kunjungan dari Institut Teknologi Indonesia (ITI) Serpong, Universitas Indonesia, dan UIN Jakarta. Berdasarkan Gambar 9 terlihat bahwa jumlah kunjungan mahasiswa Institute Teknologi Indonesia (ITI) Serpong cenderung menurun dari tahun ke tahun. Hal tersebut disebabkan mahasiswa yang berkunjung ke UPJ PDII-LIPI Serpong hampir seluruhnya dari Fakultas Teknik (khususnya Jurusan Teknik Kimia) dan koleksi buku tentang teknik kimia jumlahnya sangat terbatas.

\subsubsection{Kunjungan dari Masyarakat}

Masyarakat yang berkunjung ke UPJ PDII-LIPI Serpong biasanya untuk tujuan mencari informasi di internet (dengan membawa laptop sendiri); mencari informasi teknologi tepat guna (TTG); membaca dan konsultasi. Tabel 7 menunjukkan jumlah pengunjung ke UPJ PDII-LIPI Serpong dari kelompok masyarakat atau umum. 
Tabel 7. Jumlah Pengunjung dari Kelompok Masyarakat

\begin{tabular}{|c|c|c|}
\hline Tahun & $\begin{array}{c}\text { Jumlah } \\
\text { (orang) }\end{array}$ & $\begin{array}{c}\text { Persentase } \\
(\mathbf{\%})\end{array}$ \\
\hline 2010 & 4 & 2,78 \\
\hline 2011 & 9 & 6,25 \\
\hline 2012 & 14 & 9,72 \\
\hline 2013 & 35 & 24,31 \\
\hline 2014 & 67 & 46,53 \\
\hline 2015 & 10 & 6,94 \\
\hline 2016 & 5 & 3,47 \\
\hline Total & $\mathbf{1 4 4}$ & $\mathbf{1 0 0}$ \\
\hline
\end{tabular}

Pada tahun 2010 - 2014 jumlah kunjungan dari masyarakat mengalami peningkatan. Namun dalam kurun waktu dua tahun terakhir jumlah kunjungan masyarakat mengalami penurunan. Ketika berkunjung ke UPJ PDII-LIPI Serpong, petugas memberikan bimbingan akses informasi yang tersedia di PDII-LIPI melalui internet tanpa harus datang ke perpustakaan - sehingga pengguna dapat mencari kebutuhan informasinya secara mandiri tanpa harus datang ke UPJ PDII-LIPI Serpong.

\subsubsection{Kunjungan dari Kelompok Industri}

Pada umumnya informasi yang dicari oleh pengguna kelompok industri adalah informasi standar, seperti ASTM, British Standard, ISO, JIS, SAE, SNI, dsb. Gambar 11 menunjukkan jumlah kunjungan dari kelompok industri pada tahun 2010 - 2016.

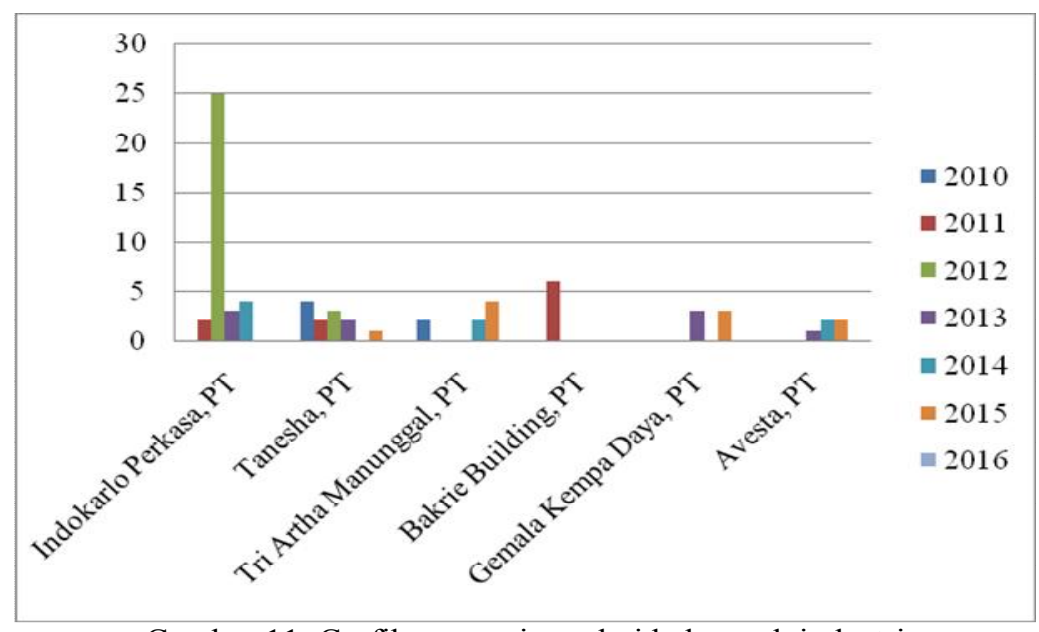

Gambar 11. Grafik pengunjung dari kelompok industri

Berdasarkan hasil wawancara dengan pengunjung dari kelompok industri, ada beberapa hal yang menyebabkan penurunan kunjungan ke UPJ PDII-LIPI Serpong, antara lain: (1) mereka memerlukan informasi berupa standar yang harganya cukup mahal, sementara dana perusahaan untuk pembelian informasi standar sangat terbatas; (2) banyak industri yang menjadi anggota Masyarakat Standarisasi (MASTAN) sehingga untuk mendapatkan dokumen standar akan mendapatkan potongan harga yang cukup besar (sekitar 20\% atau lebih); (3) semakin banyaknya penerbit standar yang membuka toko online sehingga industri dapat membeli informasi standar langsung ke penerbit dengan harga lebih murah dari pada membeli melalui UPJ PDII-LIPI Serpong. 
Gambar 12 menunjukkan sepuluh kelompok industri yang berkunjung ke UPJ PDII-LIPI Serpong pada tahun 2010 - 2016. Dalam kurun waktu tersebut terlihat bahwa pengunjung UPJ PDII-LIPI Serpong dengan jumlah terbanyak adalah PT.Indokarlo Perkasa yang berlokasi di Cibinong, Bogor, Jawa Barat.

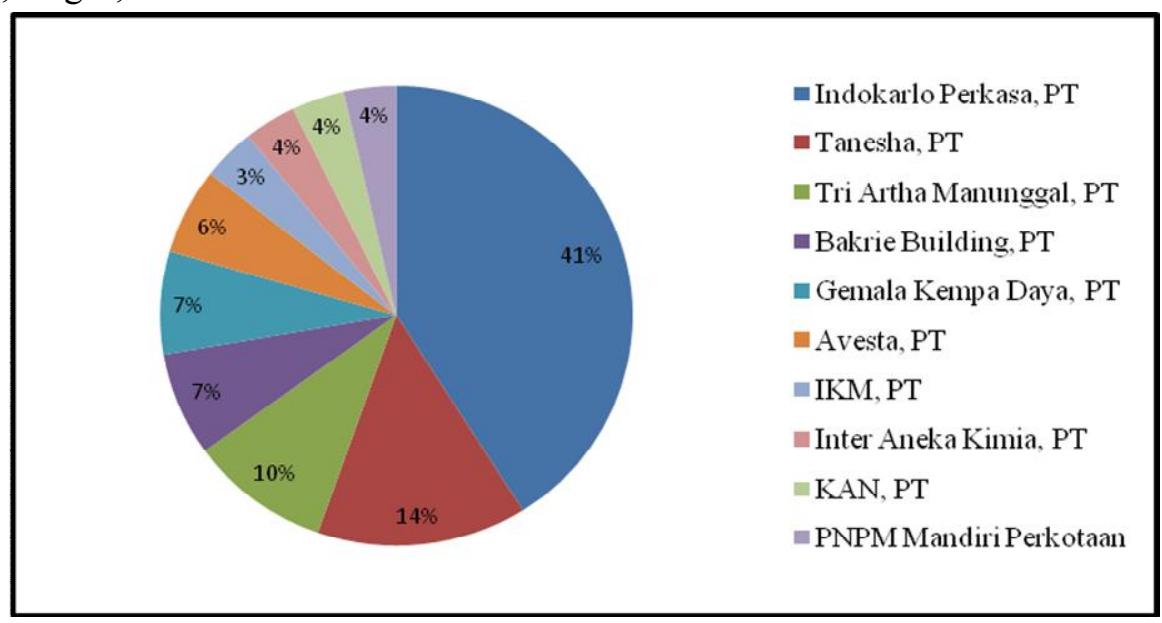

Gambar12. Diagram pengunjung dari kelompok industri (10 besar)

\subsubsection{Kunjungan dari Luar Kawasan Puspiptek}

Pada tahun 2010 - 2016, UPJ PDII-LIPI Serpong banyak menerima kunjungan dari berbagai instansi di luar kawasan Puspiptek Serpong. Sebagian besar mereka berasal dari Balai Besar Keramik Bandung; Badan Pengawas Tenaga Nuklir (BAPETEN); LAPAN; Departemen Kelautan; Masyarakat Nano Indonesia; Balai Penelitian Tanah Bogor; dsb. (Gambar 13).

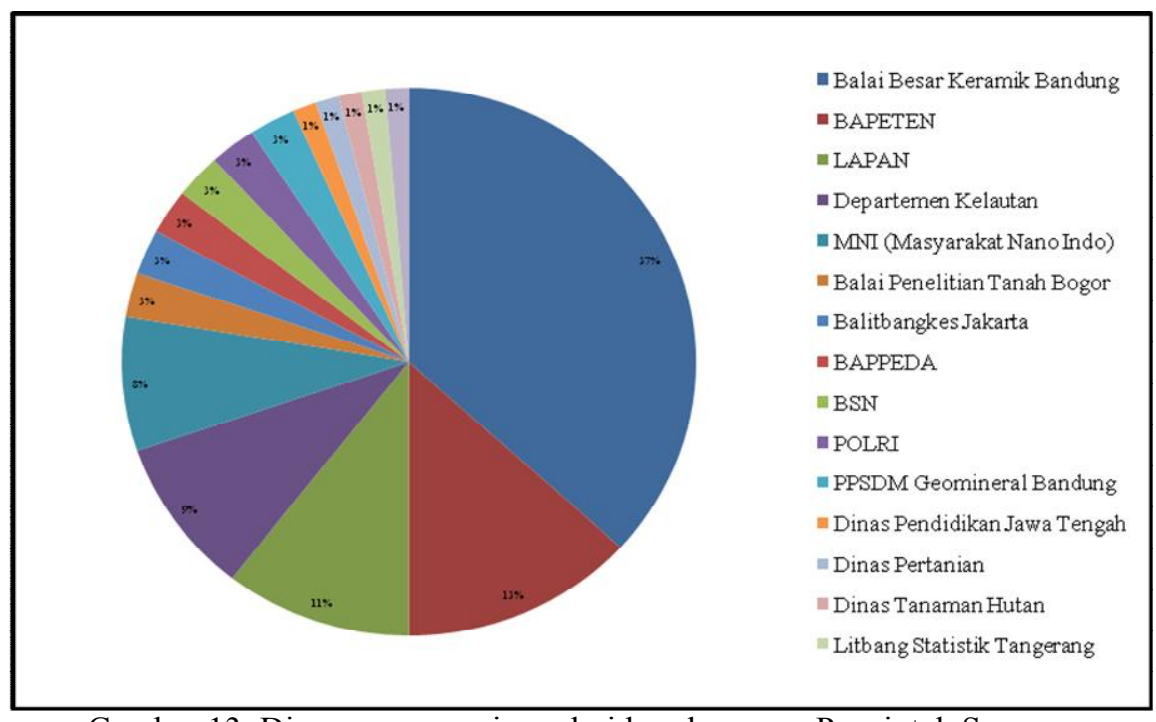

Gambar 13. Diagram pengunjung dari luar kawasan Puspiptek Serpong

Berdasarkan Gambar 13 terlihat juga bahwa Balai Besar Keramik Bandung merupakan pengunjungdengan jumlah terbanyak, yaitu 28 kali (36,84\%). Kemudian, diikuti oleh BAPETEN (10 kali atau 13,16\%) dan LAPAN (8 kali atau 10,53\%). Tujuan mereka datang ke UPJ PDII-LIPI Serpong adalah untuk artikel jurnal asing yang dilanggan LIPI maupun Kemenristek-Dikti, koleksi buku dan standar, dan kunjungan studi banding. 


\section{KESIMPULAN}

Berdasarkan hasil dan pembahasan dapat disimpulkan bahwa: (1) jumlah keseluruhan pengunjung UPJ PDII-LIPI Serpong pada tahun 2010 - 2016, yakni 2331 orang (41,8\%), yang berasal dari dalam kawasan Puspiptek; dan 58,2\% dari luar kawasan Puspiptek; (2) pengunjung dari dalam kawasan Puspiptek didominasi oleh LIPI. Sementara pengunjung dari luar kawasan Pustpitek didominasi oleh kalangan pelajar; (3) tujuan pengunjung ke UPJ PDII-LIPI Serpong, adalah mencari referensi, observasi, studi literatur, studi banding, membaca, browsing internet, membuat laporan penelitian, dan konsultasi tentang perpustakaan; (4) penurunan jumlah pengunjung di UPJ PDII-LIPI Serpong disebabkan informasi yang dibutuhkan sebagian besar sudah dilanggan oleh Kemenristek-Dikti. 


\section{DAFTAR PUSTAKA}

Audit Commission. 2002. Building Better Library Services: Learning From Audit, Inspection and Research. Di http://www.audit-commission.gov.uk/Products/NATIONALREPORT/9D0A0DD1-3BF9-4c52-9112- 67D520E7C0AB/ACKLibrariesbr.pdf (akses 20 Februari 2018).

Fransisca, Devy. 2013. Motivasi Kunjungan pada Perpustakaan Umum (Studi Deskriptif Mengenai Motivasi Kunjungan pada Perpustakaan Umum Kota Trenggalek). Media LibriNet, Vol.2, No.2 Juli.

Hasanah, Dina Fiki. 2013. Faktor-Faktor yang Mempengaruhi Minat Kunjung Pemustaka di Perpustakaan Fakultas Kedokteran Universitas Gadjah Mada. Yogyakarta: UIN Sunan Kalijaga.

Lance, K. C., Hofschire, L., \& Daisey, J. 2011. The Impact of The Recession on Public Library Usein Colorado. Closer Look Report. Denver, CO: Colorado State Library.

Mardion, Intan, Rahman, Arif, \& Yuniarti, Rahmi. 2013. Perbaikan Pelayanan Perpustakaan Berdasarkan Integrasi Dimensi Kualitas Jasa dan Pendekatan Perilaku Konsumen (Studi Kasus Perpustakaan Universitas Brawijaya, Malang. Jurnal Rekayasa dan Manajemen Sistem Industri, Vol.1, No.1,173-182.

Meisyaroh, Isti. 2014. Faktor-Faktor yang Mempengaruhi Minat Kunjung Pemustaka di Kantor Arsip dan Perpustakaan Kabupaten Klaten. Yogyakarta: UIN Sunan Kalijaga.

Rao, K. Nageswara \& Babu, K.H. 2001. Role of Librarian in Internet and World Wide Web Environment. Informing Science, Vol.4, No.1, 25-34.

Rulyah, Siti. 2006. Meningkatkan Mutu Layanan Perpustakaan dengan Dukungan Teknologi Informasi: Kendala dan Tantangan di UPT Perpustakaan Sriwijaya. Jurnal Kepustakawanan dan Masyarakat Membaca, Vol.22, No.2, 15-26.

Shen, Lan. 2006. Designing and Implementing Alternative Library Services. Di http://www.white-clouds.com/iclc/cliej/cl22shen.htm (akses 18 Februari 2017).

Subagyo. 2009. Analisis Pengunjung dan Sirkulasi Buku Tercetak: Studi Kasus Terhadap Mahasiswa Starata Satu pada Perpustakaan Pusat IPB. Visi Pustaka, Vol.11, No.10, 34-43.

Suhartika, I Putu. 2004. Implementasi Teknologi Informasi sebagai Usaha Peningkatan Mutu Layanan Perpustakaan. Visi Pustaka, Vol.6, No.2,15-18.

Witjaksono, Arief. 2009. Peningkatan Kualitas Layanan Perpustakaan Perguruan Tinggi Pendekatan Manajemen Mutu Total. Buletin Perpustakaan Universitas Airlangga, Vol.4,No.1, 20-27. Surabaya.

Yadnya, I Made Sudja. 2006. Peranan Promosi terhadap Layanan Perpustakaa. Oryza, Vol.5,No.2, 156-166.

Yadnya, I Made Sudja. 2007. Upaya Peningkatan Kualitas Layanan Perpustakaan. Oryza, Vol.5, No.4,106-115. 